\title{
[8]
}

\section{The Impact of Second Republic Labor Reforms in Spain}

\author{
George A. Collier
}

What is the relationship between legislation and legal change? And how does one best come to understand the experience of legal change for those whose lives legislation affects? When we examine such issues concerning how legal institutions and processes reach into, shape, and are shaped by daily affairs in the lives of communities and individuals, we must consider questions of power, of meaning, and above all of their historical interplay.

Power must be a consideration, because the forms that laws take and the impact of those laws at the local level are each shaped by political struggle that is not static but constantly in tension, in flux. Legislation will be the outcome of political struggle, and sometimes it will even result from contention for control of the state itself. But legislation can also shape the context and trajectory of political struggle, creating within the political order new space over which old parties may contend and within which new interests may emerge, as Francis Snyder has illustrated in his discussion of the European Economic Community. Local communities, asymetrically embedded as they often are in larger fields of power relations, experience the consequences of the political flux that ensues from legislation, and sometimes contribute to it.

Meaning must be a consideration, because signification always exceeds intention, in the legal arena as in any other. What legislation 
means to individuals differs in relation to each person's goals and objective interests according to the contextually and culturally specific terms in which they interpret their experience. The meaning of legislation in local communities may diverge substantially from what the legislators intended, especially insofar as signification will reflect the situationally specific terms in which those in local places interpret the law. Implementing agrarian decrees of the Spanish Second Republic in terms that drew meaning from customary property and employment relations, the villagers I discuss in this chapter imparted to the legislation meanings of personhood and honor quite different from those the lawmakers in Madrid probably envisioned.

The outcome of legislation thus involves both power and meaning, and the interplay resulting from the various interpretations given to and taken from the law in the politics that ensue from it. This chapter explores such consequences of early Second Republic agrarian reforms in Spain in terms of how the Socialists implemented and experienced them in an Andalusian sierra town that I shall call Los Olivos. The Socialists were strong advocates of agrarian reform in the Second Republic. As ministers in the coalitional provisional government of April 1931, Socialist leaders decreed reforms in agrarian employment. But these decrees, and the intention of adding land reform to them, inflamed conflict, particularly in the agrarian south. That conflict welled up into politics at the national level, setting back the advocates of land reform and watering down the terms in which land reform was finally legislated.

The intention here is to illuminate the impact of the reforms legislated for agrarian employment by studying the political struggle through which rank-and-file Socialists effected the reforms. The implementation was hard fought in Los Olivos, as elsewhere in the south, where disappointment and frustration with the slow pace of land reform is thought by historians to have radicalized the Socialist rank and file and eventually party leaders. But in Los Olivos the labor reforms radicalized the Socialists in a different way-by instilling a sense of accomplishment in them.

The measure of the Los Olivos Socialists' achievements should be in the terms of goals they sought in the concrete lived experience of their circumstances. Scholars have placed a great deal of emphasis on Second Republic land reform, but this is not what the Socialists of Los Olivos were concerned with, nor was it the sole concern of militant agrarian workers elsewhere in Andalusia. In Los Olivos the relationship of proprietor to employee, to which ownership of the means of production 
gave rise, was much more immediate than land tenure per se. And it was over jobs and working conditions, not land, that agrarian workers battled proprietors, winning revolutionary changes in relations of employment.

The revolutionary character of their struggle becomes intelligible only when understood in terms of the cultural meanings of owning property and working for wages in Los Olivos. Property enabled a man to be autónomo-self-sufficient and independent of any other person's beck and call. Lack of property forced a man to bow his head to others in order to support his family, and it made him suppress his own will in any matter that might anger his employers. Villagers experienced autonomy with reference to the familiar Mediterranean idiom of honor-masculine honor and family honor. The self-sufficient could assert their own honor, and they could question it with respect to those who demonstrated their insufficiency by having to labor for wages. Customary usages had developed around wage labor, ameliorating but not eliminating the inherent humiliation of wage labor.

When the Socialists took power in Los Olivos in 1933, they revolutionized employment by seizing for labor the prerogative of determining what land should be cultivated, by whom, and when. Stripping proprietors of their autonomous power to decide such matters, the Socialists deprived landownership of its cultural meaning and inverted the relationship of employer to employee. Thus, although they acted on the basis of early Second Republic agrarian legislation, whose intent was reformist, they did so in ways that were revolutionary for the manner in which they lived and worked.

\section{The Early Second Republic Agrarian Legislation}

By allying with modern Republicans at the outset of the Spanish Second Republic, the Socialists won significant reforms for agrarian labor. ${ }^{1}$ To analyze these reforms and their effects, we must situate them in the context of political struggle that shaped them and that they in turn engendered. The Socialist alliance with moderate Republicans was a tactic in ongoing competition among leftist groups for preeminence in working-class leadership. The agrarian reforms were an initial victory for the Socialists. Over the first two years of the Second Republic, however,

1Preston 1978 gives the most nuanced account of the role of the Socialists in the Second Republic. I have also drawn from Herr 1971 in this account. 
the reforms themselves gave rise to a reaction that embattled Socialists and moderate Republicans from the right as well as from the left.

Socialist participation in the government of the Second Republic came at a time when the Socialists were consolidating gains in the organization of agrarian labor at the expense of other working-class groups, notably the rival anarchists. In contrast to anarchists, who opposed a centralized state in every form, the Socialists had a history of compromising with the employing classes in order to advance socialism through legislation and collaboration in government. In the 1922-30 dictatorship of Primo de Rivera, the Socialists had collaborated opportunistically with the government, at least initially, enabling their Unión General de Trabajadores (UGT) to expand while the government closed down rival leftist organizations or forced them underground. Although the Socialists distanced themselves from Primo de Rivera toward the end of his regime, they strengthened their position by participating in Primo's program of arbitration committees for setting wage levels and settling labor disputes. During Primo's regime, and after his downfall in early 1930, the Socialists, through their Landworkers Federation (FNTT), made considerable headway in organizing agrarian labor, rivaling the anarchists on their own turf in the south.

Thus it was that moderate Republicans embraced the Socialists as trustworthy spokesmen for labor in the early Second Republic. The Second Republic was formed in April 1931 with a provisional government coalition of right-wing Progressives, Radicals from the center, and on the left four urban middle-class parties. Of the working-class parties, only the Socialists were in the coalition. Socialists were given three posts in the Republican coalition - the minister of justice, minister of finance, and minister of labor, the latter held by Francisco Largo Caballero. The Socialists used their posts to press for reforms in favor of the agrarian workers then flocking into their Landworkers Federation and the UGT. At one of the first cabinet meetings, the Socialists agreed to postpone land reform in return for immediate action on a number of other measures to alleviate agrarian unemployment and to aid poor tenant farmers. The reforms took shape in a series of edicts during the first ten weeks of the Second Republic, later embodied in legislation after the Cortes (parliament) completed drafting the new constitution.

Certain of the edicts regulated leases benefiting small tenant farmers, prohibiting landowners from expelling them in fear of future expropriation of leased property. The edicts called for rent reductions when justified by declines in a property's level of income. They gave formally 
constituted workers' societies preference in obtaining new leases of large properties. Other edicts enacted reforms designed to better employment. They set an eight-hour day. They set up "mixed juries" representing labor, property owners, and local government to arbitrate local disputes and to enforce labor legislation. They mandated preferential hiring of laborers within the municipal boundaries of an employer's property, and they required that owners either work their lands or turn their production over to local laborers.

These were significant and controversial policies in that they gave both labor and the state a role in setting the conditions for contracts that employers had theretofore been able to set independently. As Malefakis (1970:170) has emphasized, and as proved to be the case in Los Olivos, "the agrarian decrees of the Provisional Government constituted a revolution without precedent in Spanish rural life. For the first time, the balance of legal rights swung away from the landowners to the rural proletariat." In addition, the state set about to alleviate a crisis of unemployment by using the budget at all levels of government to hire labor for the construction of public works. In this way, public funds for public works to employ laborers within the framework of the new legislation began to be distributed to towns through provincial councils.

Socialists thus delivered significant legislative reforms to their growing agrarian constituency, but implementing the reforms was another matter. Growing opposition from the right during 1931-33 blunted the progressive thrust of the Second Republic, and the government had to fend off pressures from the left for more militant and revolutionary changes.

Resistance from the right developed as monarchist sympathizers and defenders of the traditional order fought for their privilege and power. While some groups plotted the overthrow of the Republic, others attempted to thwart proposed reforms by legal means. As the Cortes began to draft a constitution, the right rallied to defend the church from provisions to cut off state support for clergy and religious orders and to limit church wealth. The church joined the right in belligerent propaganda to found a mass right-wing coalition of non-Republican forces, out of which emerged the Confederación Española de Derechas Autónomas (CEDA) in February 1933. CEDA grew rapidly in agrarian areas by whipping up fears among small landholders that their property would be expropriated, and by lobbying for higher prices for wheat-a tactic that would benefit landowners at the expense of workers. And CEDA lobbied against the existing labor legislation and attempted to stall or 
reverse legislation on agrarian leases or on proposed land reform. The right encouraged landowners to thwart labor by refusing employment to union workers and by withholding land from production or turning it into pasture.

As part of the governing coalition, Socialists at the national level were in a dilemma because resistance from the right elicited ever greater militancy on the left. Anarchist agitation and the use of the strike were growing in response to rightest provocation, yet the Socialists, in the government, were committed to sustaining legal order even in the face of militancy from within their own ranks. Thus the Socialists' accomplishments on behalf of the agrarian worker were problematic at best during the first two years of the Second Republic.

\section{Opposition to Reforms in Early Second Republic Los Olivos}

In local places as much at the national level, Second Republic agrarian reforms took on meaning in political struggle. Local opposition to progressive early Second Republic reforms was strong in Los Olivos. To begin, a propertied elite firmly entrenched in municipal governance used reactionary tactics to attempt to break the fledgling socialist Syndicate of Agrarian Workers, which in turn struggled for the right to represent labor within the framework of early Second Republic agrarian legislation. It took the intervention of the provincial government to secure the union's rights, but in a context that rightists continued to dominate.

The political history of this struggle became known to me through ethnohistoric method attuned to issues concerning class, and this is pertinent to the historical theme of this volume. The Second Republic was an era that few villagers discussed forthrightly with Jane Collier and me in the 1960s, and they did so only later, after Franco's death and the election of the current Socialist government. Even now we have been able to make sense of Second Republic events only through methods designed explicitly to explore issues of class in systematic terms. We learned a great deal through interviews about family history-but especially about working-class poor, many of whom were killed in 1936because one basis for our interviewing was the systematic and exhaustive reconstruction of the town's poulation from vital registry and census data that included individuals of all classes, many of whom would other- 
wise have been overlooked, forgotten, or left unmentioned. Los Olivos' Second Republic town hall minutes brought to life the inner maneuvering of protagonists in their struggle over agrarian issues, but once again the struggle's class dimensions became clear only by linking events to the class position of the protagonists as reconstructed from tax records and occupational categories in censuses.

Let me introduce Los Olivos from the standpoint of the politicaleconomic background of this struggle. Preindustrial, labor-intensive capitalist agriculture complemented peasant agriculture in Los Olivos in the 1920s. A community of less than 1,000 inhabitants, Los Olivos was one of several villages oriented to Aracena, the administrative and principal agrarian market center in the sierra of northern Huelva, the westernmost province of Andalusia. In the nineteenth century, agrarian entrepreneurs had absorbed church property and town commons into agrarian estates and had passed power as a landed oligarchy to their descendants in this century. Celestino López, Los Olivos's cacique, or political boss, was part of this oligarchy. His power inhered in the employment he could offer on lands that comprised one-fourth of the municipality, and in being able to deliver the vote to the political machinery of both the provincial and the national government. It was against López's control of agrarian employment that the Socialists struggled.

Lesser agrarian proprietors and merchants from a handful of interrelated families shared power with López. Most important among these were the Morenos, who were prominent in commerce linking Los Olivos through the market town of Aracena to suppliers in Seville and Huelva. Moreno family members had served as mayor and justice of the peace. Two had controlled the church and the school. Some of the Morenos were progressives who were to take part in the Socialist union leadership; others were staunch conservatives.

Below the López and Moreno families were peasant smallholders and a sizable stratum of landless and frequently unemployed poor who labored for wages in the production of olives, hogs, fruit, vegetables, cork, and grains. In the 1920s many of these poorer worker and smallholding families of Los Olivos had been at the mercy of López for seasonal employment. These laborers, and many smallholders who eventually joined them, made up the rank and file of the Socialist union that contested López's power.

López had used reactionary means to control the town council in the 1931 elections that ushered in the Second Republic. Resorting to the 
tactics by which rural caciques had perpetuated their control of public office, López prevented the putting up of an opposition slate and took office himself under the terms of Article 29 of the municipal code. This article held that a slate that had "no opposition" could dispense with an election. Taking office with López were his manager, Patricio López, and several other men of property.

Socialists in Los Olivos quickly engaged López in a struggle to control municipal public works, prefiguring future battles over control of agrarian employment. Unemployment was on the rise in Andalusia in 1931 because of drought. Everyone agreed that it was the role of the state to alleviate unemployment through local public works. What was at stake in Los Olivos was the prerogative to determine who the "needy workers" were and how jobs should be provided to them. The Socialists claimed that prerogative for their Syndicate of Agrarian Workers.

The syndicate drew most of its initial rank and file from poorer townsfolk, among them muleteers and men who farmed tiny properties and worked seasonally for wages. The union was led by progressive men, several of them agemates, from wealthier Los Olivos families closely related to the conservative, traditional power-holders. Thus Ceferino Santis, president of the syndicate, was brother to one of López's councilors and allies. And Pablo Moreno, the syndicate's young ideologue, was from a merchant family that had sent him to work in a Seville store where he had been radicalized.

The basis for conflict over the control of public works inhered not only in the contending claims of two institutional bodies, the syndicate and the town council, but also in the ambiguity of who the needy unemployed were and to which body were they allied. The syndicate sought to represent families that made most of their living through wage labor. Yet Celestino López's faction included laborers as well. It included families that the rich patronized with year-long employment on local estates. And it included masons, ostensibly laborers in that they worked for wages, who enjoyed continual employment in rebuilding houses of the wealthy; masons also supervised most public construction funded through the town council. Many women and youth depended on domestic work for the wealthy, and thus dared not oppose them. Finally, the class position of many smallholding farming families was ambiguous, as youthful members worked for wages but aspired to some degree of autonomy that inheritance of smallholdings would eventually give them.

It was in this context that conflict over public works developed in Los Olivos during the summer months of 1931 after employment in the 
wheat harvest ended. Celestino López secured funds to repave several village streets and began hiring favored workers, in the name of the town council, to undertake the work. The syndicate contested the legitimacy of this employment, claiming the prerogative to determine who were needy laborers and insisting that workers had to join the union to be eligible for wages paid from public funds earmarked to relieve the unemployment crisis. Celestino López threatened to put the paving up for public bidding, a tactic that would probably have awarded the work to independent masons. The syndicate responded by violently disrupting the town council session of September 23, 1931, causing Celestino López to appeal to the provincial governor to send an official representative to restore order in the town.

The governor's representative arrived from Huelva on September 24, empowered by the governor to take whatever steps he saw fit to settle Los Olivos' conflicts. After hearing the grievances against the town council, he removed López and his manager from the council, but in so doing he turned its presidency over to one of López's associates, effectively leaving the town government in control of the López faction. The tactic served as something of a compromise to stem the conflict. At the same time, however, he ordered the council to cooperate with the syndicate in forming a junta de policía rural to draw up the Bases de Trabajo to regulate employer-worker contracts, steps provided for by the decree and legislation of the Ministry of Labor that López's council had never undertaken. By this act the governor forced the town council to recognize key provisions of the Second Republic's agrarian decrees that they had ignored, legitimating a specific role for the syndicate in the local management of labor relations.

Several months of uneasy compromise between the council and the syndicate ensued. The bodies collaborated in ongoing public works for a time, and they revived an older plan to construct a new entrance road to the town, exacting promises of funding from the governor. Yet the compromise satisfied neither faction. As it broke down, the councilors repeatedly tendered their resignations, only to have the governor insist that they remain in office pending completion of Republican legislation reforming the norms of municipal government.

The councilors thus served under protest for the remainder of 1931 and throughout 1932, and it was probably not with enthusiasm that they implemented such Second Republic measures as the establishment of a local employment office in which employers were supposed to list all their job openings and workers their availability for hire. For its part, in 
the early spring months of 1932 the syndicate renewed its complaints to the governor about the council's abuse of its responsibilities.

Substantively, the battle over who should be deemed needy labor continued even as ambiguities of class position between the two factions began to be sorted out. The syndicate wanted to monopolize representation of all workers as against proprietors by gaining control of the town council itself. It thus advocated ousting the council, and free elections to replace it, as the remedy for a host of charges against the council submitted to the governor in early July:

We as Agrarian Socialists, protest the comportment of the Town Council, constituted under Article 29, for the most part made up of men who held office under the Dictatorship, all of them Monarchists in opposition to this Republic of Workers.

While thirty fathers lacked even bread to feed their children, this dignified council spent municipal funds to pay for music and religious sermons during the fiesta of San José. They obliged the priest to parade the patronal saint through the town under armed guard, attempting thereby to provoke public violence. But we Workers recognized this act as a provocation, as an attempt to get us to shed our blood in the streets and thus to break up our Union, something that will not happen even if the streets should be washed in our blood.

This Town Council is wholly in the service of the great Cacique, who threatens workers who seek employment from him and has them jailed. The council spent all of the tax surcharges for public works in paving a street that only goes to the Cacique's front door. . . .

Because we could add innumerable charges to this list, we petition you to remove from office the councilors and above all . . . to order the election of a Council by popular vote. We trust that Your Excellency will see justice done. May Your Excellency live many years in favor of the Republic.

The governor asked the council to respond to these charges point by point, but he seems to have taken no explicit formal action to sanction the council.

In the first two years of the Second Republic, Los Olivos thus experienced continuing oligarchical domination of municipal institutions. Local power-holders allowed only token innovations of the Second Republic-the secularization of the cemetery, the opening of public schools, the naming of streets in honor of Spanish intellectuals, artists, and statesmen. In this context the Socialist workers union won grudging recognition and state backing of its legitimacy, but it was not until 1933 
that local Socialists came to power in their own right and brought the agrarian legislation passed two years earlier fully into effect.

\section{Los Olivos Socialists in Power, 1933-1934}

López had constituted the town council by circumventing elections under Article 29 of the municipal code at the outset of the Second Republic. Such abuse posed a widespread problem. The remedy finally decided on was to replace councils constituted that way with administrative bodies representing labor, property, and the state while preparing for municipal elections under a reformed code that would ensure popularly elected councils.

In Los Olivos the interim council took office in January 24, 1933. Niceto Ortega, the schoolteacher, headed it in his capacity as public employee. As interim mayor, Ortega set out to improve and broaden education. He also collaborated closely with the Socialists. He joined the syndicate leaders in a visit to the governor to persuade him to concede funds for public works to build a new entrance road to Los Olivos. He also allowed them to rent a building owned by the town for the Casa del Pueblo, the public salon for UGT members and affiliates with facilities for party assemblies and a reading room with newspapers and leftist literature. The Casa del Pueblo was where the syndicate conducted its business, drawing up lists of workers resident in the municipality who were eligible for local employment. Finally, Ortega oversaw Los Olivos' first open municipal elections of the decade, on April 23, which the Socialist slate won.

The Socialists did not come to power at the most auspicious moment. By April 1933, Azaña's coalitional government had been shaken by the growing outcry against the January massacre of anarchists at Casas Viejas, Cádiz, who had momentarily seized power from the Civil Guard in an abortive uprising (Mintz 1982). The Socialists, as collaborators in the Azaña government, suffered from this opprobrium. The more general reaction that set in would lead to a rightist electoral landslide in 1933 and to the undoing or stilling of many of the reforms favoring the rural proletariat. Los Olivos' Socialists shared the adversity of these setbacks throughout their incumbency from April 1933 to October 1934.

Yet the Socialists accomplished much by way of local governance that they could be proud of. For the first time they held a majority in the bodies managing local labor relations, and they immediately used their 
position to wrest advantages for labor from the town's employers. Their first step was to raise workers' daily wages from 4 pesetas to 4.50 pesetas. They also called property owners to a public meeting to demand that they hire more workers and that they pay an advance on their property taxes for the council to use in public works employment. There is no record of what transpired in the meeting, but it cannot have been successful, for a few days later Santis petitioned the governor to send a representative to intervene with employers on behalf of laborers.

The Socialists' proudest achievement was the public works construction of a new entrance road for Los Olivos. In July 1933 the provincial government finally awarded them the contract for the long-awaited project. The contract gave them a year in which to build the road, and the syndicate dedicated almost all its energies to organizing the construction. Only members of the syndicate could labor on the project, using dynamite, pickaxes, and shovels to blast and grade a roadbed out of a granite hillside.

Looking to the future, and probably responding to Ortega's role in paving the way to their incumbency, the Socialists began to plan a complex of school buildings in Los Olivos. Under the most recent legislation, the state could provide a nearly total subsidy for such construction in a town of Los Olivos' small size.

The Socialists thus seized the opportunities provided by incumbency with considerable boldness. Their seventeen-month reign was a relatively proud one. They refurbished the Casa del Pueblo. They set up a bar de izquierdas, a leftist bar that counterposed itself to the López Casino. To make the town more attractive, they ordered property owners to whitewash all the buildings facing the streets. The roadway itself was the most tangible symbol of the syndicate's accomplishments, and even now rightists of Los Olivos grudgingly credit the Socialists with this major achievement. But more important even than the road was the Socialists' revolutionizing of labor relations in Los Olivos.

\section{Land, Autonomy, and Labor Relations}

During their seventeen-month incumbency in the town hall, the Socialists advanced and consolidated their organization and control of employment on the basis of the initial agrarian decrees and related legislation. In doing so, they laid the groundwork for revolutionary challenges to relations of production in Los Olivos. Yet these challenges 
did not involve reparto, the redistribution of property sought elsewhere in Spain by agrarian revolutionaries and enabled in moderation through land-reform legislation in September 1932. In order to appreciate the accomplishments of the Los Olivos Socialists, we must understand why they eschewed land reform and in what sense their labor initiatives were revolutionary. That is to say, we must analyze the meaning that the labor initiatives assumed in the lived experience of those hiring workers and those who worked for others.

Although we cannot be absolutely sure that the Socialists did not press for land redistribution in Los Olivos, I am convinced that it was not an important goal. There is not one mention of land reform in the hundreds of pages of town council minutes, litigation, and other documentation I have examined, and Los Olivos is not mentioned in state bulletins that reported land-reform initiatives. While this is negative evidence, the recollections of villagers support it.

One possible reason that redistribution was not sought is that land was much more equitably distributed in Los Olivos than in other Sierra de Aracena municipalities. The totally landless were not as numerous in the populace of Los Olivos as elsewhere. Many day workers had small holdings.

More important, Los Olivos Socialists probably avoided advocating land reform to avoid alienating smallholders from their cause. Smallholders in Los Olivos were more amenable to the Socialist cause than were their counterparts in such areas in Castile. Unlike peasants in Castile, whose experience with day workers was with laborers brought in at harvesttime from other towns and cities (Pérez Díaz 1976:125), smallholders in Los Olivos were closely tied to day workers in their town. Many were related to one another, members of smallholding families often worked side by side with day laborers to supplement subsistence farming. Hence, a worker-peasant alliance was quite justifiable in Los Olivos, and when the Socialists offered employment in public works during their incumbency in the town council in 1933-34, many smallholders did join the syndicate to avail themselves of jobs.

The Socialists thus united laborers and peasants in work, setting aside land reform-if it was in fact ever a goal. Instead, the relationships of work, of employer to employee, prove to have been central to alliances and cleavages in Los Olivos, much more so than differences in ownership of property per se.

To explain why relationships of employment were so significant, I must say something about the cultural meaning of autonomía. Villagers 
of Los Olivos held to the ideal of masculine autonomy that was characteristic of property relations in agrarian societies of the Mediterranean. The property system brought together a couple's productive assets and vested the care of those assets in the male head of household. A family estate of sufficient size enabled a man to protect and develop his family interests with autonomy. Such a man could do what he wanted, free from others' control, including standing up to others to protect his family's honor.

Inequalities of wealth made it impossible for all men to live up to the ideal. Men who controlled insufficient property had to bow their heads in subservience to employers. Such men sacrificed autonomy perforce, and in doing so called into question their ability to defend family interests and honor. Conversely, the man wealthy enough to hire labor held in addition to autonomy the power to subordinate others, arbitrarily if so desired, and even in ways that might compromise the subordinate's family honor.

The ideal of masculine autonomy thus charged employer-employee relations with special tension. In having to accept someone else's orders, the employee implicitly acknowledged his lack of full autonomy and his vulnerability to potential dishonor. In giving orders, either directly or through a representative, the employer implicitly asserted his own invulnerability and power.

Many of the usages and attitudes that Juan Martínez-Alier (1971) describes as characteristic of Andalusian employment guarded against the direct threats to masculine autonomy that employment entailed. The use of foremen shielded employers and employees from direct confrontation. Through unión-emphasizing workers' solidarity and the strict equality with which what applied to one applied to all-workers not only protected their class interests but also defended against any questioning of their individual autonomy. By having well-defined standards as to what amount and quality of work fulfilled a worker's obligation to his employer to cumplir, workers not only resisted exploitation but also subtly protected themselves from appearing to have to take orders.

Seen in this light, the Bases de Trabajo of the Second Republic implicitly challenged the autonomy of the proprietor to manage his own affairs. They did so by altering customary usages of employment and by giving labor the upper hand over employers in determining relations of employment. The extent to which they did so can be seen in the Bases drawn up for the Sierra de Aracena region by the Mixed Jury for Rural 
Labor of Aracena in June 1933, just after the Socialists assumed power in Los Olivos.

In general, the Bases de Trabajo set minimally acceptable terms under which employers had to hire workers. These terms included minimum wages, extra pay for the transporting of equipment, a place to tie up and graze a mule or horse, hygienic lodging if a worker was to live on site, and so forth. Only employment at least as favorable to the laborer as specified in the Bases was permissible.

The Bases formalized workers' maximum responsibility to employers, in many instances reducing what a laborer had to do in order to cumplir. Instead of the customary work de sol a sol (from dawn to dusk), the Bases set the workday at six hours in winter and seven hours in summer, with extra hours paid as overtime. They specified reduction in the workday to compensate for any travel to work over two kilometers from a worker's home. They codified the degrees of respect that employers and workers were to show to one another, to foremen, and to these parties' families.

Worker solidarity and unión were institutionalized by the Bases in the functioning of municipal employment entities in which organized labor had a voice and often control. Laborers were to be hired on a weekly or semimonthly basis in rotation and in the strict order with which they had signed up for employment in the municipal Office of Employment and Labor Exchange. Employers could not hire workers for jobs that had not been listed in these offices. These provisions prevented employers from favoring some laborers and blackballing others. They also affirmed the dignity of work by preventing laborers from having to kowtow to employers in order to get jobs.

The Bases considerably restricted employers' autonomy in managing their agricultural property. They prohibited the use of reaping or threshing machinery and of plows in vineyards. They mandated yearlong contracts for a specific number of laborers, depending on the acreage a farmer owned and how it was cultivated. They limited the grounds on which employers could dismiss employees.

The Bases de Trabajo for the Aracena region were by no means unique in so tipping the balance of employment relations in favor of workers. Bases issued in other areas of Andalusia during 1933 were equally far-reaching. In Jaén, for example, the Bases codified the customary harvest practice of rebusca in ways that were highly advantageous to the proletariat. This practice permitted foragers to follow harvest teams into the olive groves to scavenge the fruit that had been left behind. Usually the rebusca began after harvesting was completed. 
The 1933 Jaén Bases authorized the rebusca to begin after one-fourth of the harvest was in, leading proprietors to charge angrily that they were being robbed of their harvest.

The outcry of proprietors against the Bases de Trabajo for Aracena was equally angry. "The propertied class of Aracena has its hands up while the Boletin Oficial of June 14 takes aim at them with the rifle of the Bases contained therein," railed the Diario de Huelva as it lambasted the provisions mandating hiring of workers on yearlong contracts for properties of a specified size. Indeed, the Bases were far-reaching, and in the hands of representatives of labor who also controlled municipal governance they posed the potentially revolutionary threat of completely undermining proprietors' autonomy to put property to whatever use they wanted in capitalist production.

\section{The Agrarian Experience of Reaction, 1933-1935}

Understood in cultural terms, then, the labor initiatives legislated as reforms assumed more radical significance as agrarian workers and politicians implemented them at the local level. These developments were not without their political reaction, however. In substantial measure stimulated by agrarian conflict in the south (Preston 1984), reaction surged on the right from the provincial level to the national level during 1933 and 1934, leading to increasing use of public force against the left in the name of law and order, and culminating in the overt repression of Socialists and leftists in the autumn of 1934. Spaniards refer to the period of reactionary Republican government that followed the November 1933 electoral victory of CEDA, the rightist front, as the bienio negro, a twoyear period of repression and of legislative repeal of many earlier Republican reforms.

The reaction tipped the balance of the state's agrarian concerns away from labor and in favor of proprietors. Although adhering to corporatist rhetoric that heralded agrarian workers as part of the gran familia campesina whose collaboration in work was vital for the economy, state agrarian policy in 1934 clearly aimed at getting harvests in without disruption or destruction. The government had begun to ignore earlier prolabor agrarian legislation, evoking heightened labor militancy, particularly in Extremadura. The threat of a harvest strike had been proclaimed on May Day by the Socialists, who were no longer in the government and who joined with the anarchists in the Frente Campesino 
to secure land reform and agrarian workers' rights. In response, the minister of the interior was given a free hand to prevent the strike. He instigated the wholesale arrest of towns' Socialist leaders and closed down the Socialist newspaper, El Obrero de la Tierra (Malefakis 1970:336337; Jackson 1965:134-135). In June, strikes and work stoppages affecting harvests were declared illegal. The wave of arrests extended even to Socialist deputies in the Cortes, despite their constitutional immunities (Jackson 1965:137), evoking comparisons to the fascist repressions of German Social Democrats in 1933 and the Vienna Socialists in February 1934.

It was in this context that Los Olivos Socialists began to experience reaction and repression. Having lost control of the town council, the rightist opposition took to the courts in 1933, primarily in civil suits harassing Socialist leaders. Many of them brought suits of eviction against their tenants-including several leading Socialists and their kin as defendants - under one or another pretext to rid themselves of the threat of indefinite leases on unfavorable terms. ${ }^{2}$

These and other suits prolif erated within a broader context of reaction in which successive governors of Huelva undertook to contain labor unrest. Whenever a general strike was anticipated, the incumbent governor would declare a state of alarm under the Ley de Orden Público and deploy the Assault Guard or Civil Guard to put suspects under "preventive" arrest. Preventive arrest was a common experience for the town's leading Socialists, who suspected that police forces were trying to provoke them. Socialist Mayor Ceferino Santis was arrested at least a dozen times and held without charges being brought against him.

As the threat of harvest strikes swept the country in May 1934, the arrests quickened. On May 2, the day after the Socialists had proclaimed the Frente Campesino, the governor suspended Ceferino Santis from his position as mayor and had him jailed. In early June 1934, workers went on general strike in towns throughout the province, and the governor arrested strike leaders, including Los Olivos' Socialist acting mayor.

Then in October 1934, in the wake of the Asturias Revolution and a wave of agrarian strikes in Andalusia, the governor announced orders from Madrid to remove from office every individual whose inclinations might oppose those of the state. On October 22 a large number of

${ }^{2}$ Eviction suits were a new consequence of Republican legislation in 1933, which was repealed in 1935. In Los Olivos, as elsewhere, many older property owners leased land to tenant farmers to procure income during retirement. These property owners recognized the repealed legislation as a threat to their power and their prerogatives as landlords. 
Huelva towns, including Los Olivos, received orders replacing leftists on their councils with rightists. The state of alarm suspending civil rights was extended through 1935. Hundreds of town councilors were suspended throughout Spain, and up to 40,000 union leaders and former councilors were held prisoner (Jackson 1965:161). In Los Olivos the entire council was suspended and replaced with a slate headed by Celestino López, the former cacique.

Needless to say, these developments brought Socialist agrarian employment practices to a halt. López and his co-councilors made a clean sweep of all personnel involved in town government. The syndicate having been dissolved by order of the governor, the councilors closed down the Casa del Pueblo, the Socialists' meeting place and labor exchange. They fired Socialists from jobs and allowed private employers to do the same. They hounded former Socialist council members with charges of fiscal malfeasance and persuaded the governor to instigate criminal proceedings against them.

The rightist council also collaborated with the repressive Civil Guard, which the governor used province-wide to maintain order in the face of threatened general strikes. The council enlarged and refurbished the local Civil Guard garrison, which belonged to Celestino López, who happily agreed to sell the building to the town for 9,000 pesetas. For their part, the Civil Guard made their presence felt with a vengeance. Judicial records show that citations by the officers increased thirtyfold in 1935. Almost all the citations were to poorer townsfolk allegedly caught trespassing or improperly herding in the countryside, primarily on properties of the largest landowners. It had become clear that the state had backed the conservative propertied class against agrarian workers in the Huelva countryside during the bienio negro, reversing gains made by labor on the basis of earlier agrarian legislation.

\section{The Socialist Vindication, 1936}

Despite the reversals of the bienio negro, the Socialists of Los Olivos were able to reinstate and even advance their radical transformation of agrarian employment after general elections-won by the Popular Front coalition of Socialists, Communists, and left Republicans-returned the left to power in February 1936.

There were various sources of the greater militancy with which vindicated Los Olivos Socialists now reasserted their authority. Several of 
them had been jailed in Huelva with militant anarchists and Communists during the repression. The fact that the Popular Front had brought the parties of the left together added to their militance. The Socialists subscribed to a variety of left newspapers, in addition to the party organs El Socialista and El Obrero de la Tierra, so they were abreast of the redirection of Socialist party policy to press workers and peasant organizers to take the initiative in the Spanish countryside rather than wait for the Popular Front government to act.

Theoretically, the state still exercised its legitimate dominion, but in fact the balance of power had shifted to the local level and to labor more than ever before. At the national level, Socialist leader Francisco Largo Caballero convinced the Socialists not to accept ministerial posts in the government, so that they would have a freer hand than in the first bienio to respond to the militant demands of their rank and file. The FNTT pressed peasants to undertake land invasions on their own and to protect themselves from the Civil Guard with local militias of their own (Malefakis 1970:365-366). While the Socialists in Los Olivos carried out state decrees and legislation-restoring fired workers to their jobs, reinstating juntas de policía rural, and reestablishing local commissions to administer public works. In fact, they assumed the more direct and militant control of labor relations urged by party leaders. As happened in many other towns, the Socialists formed a guardia cívico, a local vigilante group, to back themselves up.

The Socialists in Los Olivos engendered a sense of utopian expectations similar to those that prevailed elsewhere in Andalusia (Jackson 1965:222). Many people of the village believed that a time was coming in which all property would be shared. The more militant leftists went into the countryside to bring back cows and goats to slaughter. They distributed the meat free, even to families on the right.

Lacking control of the local court and of the state's coercive power, the Socialists could not suppress the right as effectively as the right had repressed them during the bienio negro. Instead, the Socialists organized labor much more militantly than ever before. They harassed independent artisans who were not union members, forcing them to do menial tasks for the council usually done by women, such as mopping the floors of the town hall after council meetings. More to the point, the Socialists pressed home their advantage over wealthy agrarian proprietors in matters of employment. They divided union members into groups and assigned the groups to work on larger estates whether the owners accepted them or not. If not, workers were to sit with their tools 
at the landowner's doorstep and demand their wages on Saturday anyway. This forceful repartimiento of labor is what villagers remember most of the spring of 1936, for it once again struck deeply at the autonomy of the property owner. It was a widespread practice, used, for example, in Ronald Fraser's Mijas (1972:106,122), which had arisen from the legally sanctioned mixed commissions of laborers and employers for regulating employment. Thus with the Socialists back in power, labor once again gained the upper hand.

Just as in 1933, agrarian laborers played their hand without attempting to seize land (as did happen in other regions at the time) because the repartimiento of labor was in itself sufficient to alter the cultural meaning of land ownership. Proprietors on the right recognized the forced allocation of laborers as an abrogation of their claimed right to manage their property and thus as a step toward its dispossession. As one man put it, reminiscing to me about the period, "We were no longer owners of what we owned." What proprietors lost was their much-cherished autonomy, their claim to being independent and hence free of any other man's beck and call. By stripping proprietors of their prerogative to set conditions of work, the Socialists had transformed the cultural meaning of property without altering its distribution. Building on what they had accomplished in 1933, the Socialists were effecting a radical transformation in the relation of employee to employer, if not in the ownership of capital. They had begun a revolution similar to that which was to sweep areas of Republican control (Bolloten 1979) after the military insurgency led by Franco broke out in July 1936.

In Los Olivos, insurgent forces took over within weeks of the July insurgency, bloodily decimating the Socialists and restoring the landed oligarchy to power. But that is another story.

\section{Conclusion}

I argued at the outset that when we study the relationship between legislation and legal change we must investigate power and meaningthe central considerations in contemporary political-economic and interpretive analyses-for two reasons. The first is that the forms that laws take and their impact on the local level are each shaped by political struggle, which can be understood in terms of the historically located class relations. At the same time, legislation shapes the context and trajectory of such struggle. The second is that the significance of legisla- 
tion is always greater than the meaning intended for it. Legislation never speaks for itself. Its meaning is a matter of interpretation and contention. It must be understood in the cultural terms with which individuals experience and interpret it in relation to their goals and objective interests.

In studying early Second Republic agrarian legislation, how it was implemented and how it was experienced, I have posed questions of power and meaning and explored their interplay. This required analysis of both legislation and implementation in terms of the political struggle surrounding them, drawing attention to the articulation of these state and local developments. Questions about the experience of implementation-about the meaning attributed to employment practices by workers and employers-have suggested fresh conclusions about the significance of the early Second Republic agrarian legislation.

Most important, I would argue that the Socialists accomplished considerably more in reforming and revolutionizing agrarian labor than historians have credited to them. The Socialists of Los Olivos devoted their full energies to the arena of employment, and they had reason to be proud of their accomplishments. Land reform, for which Socialist party leaders struggled in the Cortes and on which historians have placed so much emphasis, was of little interest to the agrarian workers of Los Olivos. At the same time, transformations in the arena of labor in 1933 took on much more radical meaning for men of Los Olivos than historians have recognized. Charged with potent local understandings of the relationship of male honor to employment relations, these labor reforms threatened to invert power relations and to undermine the meaning of property and of employment in revolutionary ways. Preston, Malefakis, and others demonstrated that pressures from rank-and-file membership radicalized the Socialists' party leadership during the Second Republic, but they attributed the pressures to discontent with the slow pace of land reform. The case of Los Olivos suggests instead that rank-and-file fervor arose as much from the experience of victories won in the radical transformation of relations of employment in local arenas.

\section{Acknowledgments}

This account of Second Republic Socialists in "Los Olivos" (a pseudonym) draws on research supported by Research Grant No. HD-17351 from the National Institute of Child Health and Human Development. 
Reconstruction of Second Republic events in Los Olivos draws heavily on the documentary record of the minutes of the town council, as supplemented by other local archival materials and oral history of the era recounted to Jane Collier and myself by villagers we interviewed. This account also draws in part on my study titled Socialists of Rural Andalusia: Unacknowledged Revolutionaries of the Second Republic, published in 1987 by Stanford University Press, to which I am grateful for permission to reproduce or paraphrase certain passages in this chapter.

\section{REFERENCES}

Bolloten, Burnett. 1979. The Spanish Revolution: The Left and the Struggle for Power during the Civil War. Chapel Hill, N.C.

Collier, George A. 1987. Socialists of Rural Andalusia: Unacknowledged Revolutionaries of the Second Republic. Stanford, Calif.

Fraser, Ronald. 1972. In Hiding: The Life of Manuel Cortes. London.

Herr, Richard. 1971. An Historical Essay on Modern Spain. Berkeley and Los Angeles.

Jackson, Gabriel. 1965. The Spanish Republic and the Civil War, 1931-1939. Princeton.

Malefakis, Edward E. 1970. Agrarian Reform and Peasant Revolution in Spain: Origins of the Civil War. New Haven.

Martínez-Alier, Juan. 1971. Labourers and Landowners in Southern Spain. Totowa, N.J.

Mintz, Jerome R. 1982. The Anarchists of Casas Viejas. Chicago.

Pérez Díaz, Victor. 1976. "Process of Change in Rural Castilian Communities." In Joseph B. Aceves and W. A. Douglas, eds., The Changing Faces of Rural Spain, pp. 123-142. Cambridge, Mass.

Preston, Paul. 1978. The Coming of the Spanish Civil War: Reform, Reaction, and Revolution in the Second Republic, 1931-1936. London.

. 1984. "The Agrarian War in the South." In Paul Preston, ed., Revolution and War in Spain, 1931-1939, pp. 159-181. London. 